Article

\title{
The Presentation of Automotive Brands in the On-Line Environment-The Perspective of KIA, Peugeot, Toyota and VW in the Slovak Republic
}

\author{
Jakub Soviar ${ }^{1, *}$, Martin Holubčík ${ }^{1}{ }^{\mathbb{D}}$, Josef Vodák $^{1}$, Miroslav Rechtorík ${ }^{1}$ and \\ František Pollák ${ }^{2}$ (1) \\ 1 Department of Management Theories, Faculty of Management Science and Informatics, University of Žilina, \\ Univerzitná 8215/1, 01026 Žilina, Slovakia; martin.holubcik@fri.uniza.sk (M.H.); \\ josef.vodak@fri.uniza.sk (J.V.); miroslav.rechtorik@fri.uniza.sk (M.R.) \\ 2 Department of Tourism and Hotel Management, Faculty of Management, University of Prešov, \\ Konštantínova 16, 08001 Prešov, Slovakia; frantisek.pollak@unipo.sk \\ * Correspondence: jakub.soviar@fri.uniza.sk; Tel.: +42-14-1513-4462
}

Received: 13 March 2019; Accepted: 30 March 2019; Published: 10 April 2019

check for updates

\begin{abstract}
This article deals with the analysis of the reputation of global automobile manufacturers primarily in the territory of the Slovak Republic for their comparison. The reputation of brands in the wider Central European and global context has also been considered. The selected brands were Volkswagen, Toyota, KIA, and Peugeot. Selected car brands either have a production plant in Slovakia or are well known in Slovakia, thanks to high global brand awareness. E-business marketing activities in the automotive sector are a major challenge to sustainability in the industry. The analysis took into account official information provided by automotive companies for the purpose of reputation management, as well as external data such as automotive media articles, independent reviews and customer feedback. The findings of the article include a detailed analysis of the online reputation of examined individual brands. The article also provides a list of the most important factors that can positively or negatively affect brand reputation, defined based on previous analysis. In conclusion, the authors try to make use of the findings and build a brief set of recommendations on how to correctly apply the reputation management principles to the overall strategy of the organization.
\end{abstract}

Keywords: online reputation; automotive industry; marketing; sustainable online reputation; Slovak republic market perspective

\section{Introduction}

The sustainability of managerial and marketing activities is increasingly focusing on the use of information and communication technologies and online reputation is one of the most useful marketing activities within E-business. The automotive industry is one of the most competitive environments and future sustainability is a challenge. This article describes and analyzes the activities of several major automakers on the Central European market.

From the era of Henry Ford's production marketing management, when demand well outpaced supply and the available product was immediately successful on the market, to the present times of hyper supply and hyper information time, the number of variables necessary to actively manage marketing activities (particularly reputation management or reputation) has multiplied to almost countless dimensions. The online environment plays an increasingly important role in customer decision-making. The same applies to brand perception. The building of it is subjected to several factors. The key role here is the experience of customers with real products and the communication of brands towards the public. Both factors are intensely penetrating the online environment. Firstly, 
customer response is faster and more dynamic. This also creates a whole network of opinion leaders and influencers and the media that provide information. Brands themselves also use all available online communication tools to manage their reputation. This article deals with important brands from the automotive industry. We chose them based on the perspective of the Slovak Republic, which is currently the leader in the production of passenger cars [1]. VW, KIA, and Peugeot have large production capacities in Slovakia. Since it is a global leader in the automotive industry, we also chose Toyota for the reference strength of their brand. In the analysis, we have always focused on the information on individual brands presented at the Central European to the international level and we have gradually focused on the situation in Slovakia. The Slovak context is essential, but not decisive, as we have always considered the wider international context.

The reputation of companies operating in the automotive industry has been investigated so far in several studies. In Slovakia, Dorčák [2] examined the online reputation of 10 best-selling automobile brands in Slovakia and found that active reputation management with online tools is capable of greatly mediating communication between the company and the public. In the global context, foreign authors [3], in their research on three automobile brands Tesla, Toyota, and Volvo, have shown a positive impact on the loyalty of customers in the automotive sector. On the other hand, the presumed direct impact of the reputation on the profit of automotive companies [4] was not shown in Sandu's research. This may point to the intangible nature of reputation as a business source.

Contrary to the above-mentioned research, our research focuses primarily on the identification of specific factors that have a positive or negative impact on the reputation of the examined automotive companies in the conditions of the Slovak Republic.

\section{Theoretical Background}

\subsection{The Position of Online Reputation}

The notion of online reputation can also be defined as the overall presence of a company on the Internet, taking into account their websites, social networks, blogs, and other means [5]. Online reputation represents a publicly held social assessment of the company. The assessment is based on past company contributions and on what the third parties have shared on the Internet [6].

It is thanks to online reputation and tools of online reputation that the company can often eliminate crisis situations that could or already did damage its name. On the other hand, more and more customers are increasingly relying on "online" opinions and other people's experiences. It is, therefore, necessary for companies to constantly monitor their activities and their own statements in the virtual environment [7]. Based on research [5], it can be argued that businesses with a good online reputation may demand higher prices for their products than those with a worse reputation. Reputation systems have been developed to monitor online reputation. These systems use the Internet to collect user opinions about products, transactions, and events, then group them, evaluate them, and make them public for all users. Online reputation systems are divided into two basic groups as follows [8]:

- Centralized systems in which central servers are used to collect, process, and distribute information;

- Scattered systems relying on a non-central structure in which reputation information is retained by the users themselves.

From a company perspective, there is no need to ask about the importance of online reputation. It is important to analyze the current state of the company and to start managing this online reputation on the basis of online reputation management. The company must try to maintain control of its brand. They should know that the number of potential customers in the virtual environment is constantly increasing, along with the availability of Internet access and the availability of information on the Internet [9].

A comprehensive approach of a company leads to the sustainability of active online marketing in a competitive automotive (not only) market. Online marketing has a direct impact on reputable brand 
management. Given the relatively open nature of the Internet, it is only a matter of time before third parties take a more prominent role in building the impact of automotive companies. In that case, a given car brand loses its direct impact on the active behaviour of the profile and the authenticity of the presented content, thus, exposing itself to an increased risk of falling under the unfavorable pressure of competition in increasingly stronger market conditions [2].

While respecting all the above, the importance of geographical identity, culture, and customer mentality can be considered. An example of this is the difference in the perception of the recent ecological case of Volkswagen, when the reputation of the company in the US suffered great damage. For this fraud, with manipulated and falsified emission tests, the company was fined $\$ 18$ billion. Eventually, Volkswagen paid the United States $\$ 4.3$ billion and an additional $\$ 14$ billion in damages to car owners (up to $\$ 10,000$ ) affected by the case, through lost court cases. The carmaker has admitted that the total bill that it must pay for the scandal will be more than the $\$ 18.2$ billion planned budget that the company planned to use to settle the case. When this fraud became public, the stock value of the carmaker fell by as much as $40 \%$, in the course of a few days, to less than $\$ 100$ per share. Although the current share value is $\$ 152$, it has not yet returned to its pre-crisis value, when it exceeded $\$ 160$. Even though the scandal broke out in the US, it had an impact on the whole world. Paradoxically, it did not affect Central Europe as much, even though diesel vehicles in Europe represent up to $41 \%$ of all cars. Even in Slovakia, there were up to 45,000 cars that had emissions deficiencies, but according to Zoroslav Smolinski, chairman of local trade unions at VW in Bratislava, the fraud did not affect them at all. There were no redundancies or wage cuts. According to the author of the article, in 2016 VW has even become a global leader in the number of cars sold, with the company estimated to have increased sales by $4 \%$, to a record of 10.3 million cars sold [2,10].

\subsection{The Bonds Between Sustainability and Reputation}

The main ideas of sustainability include the effort to preserve our planet and to pass it on to future generations at least in the state it is now. Ideally, both society and people should strive to achieve an even greater goal and apply the principles of sustainability to such an extent that each generation makes the world better than it was made by the generation before.

A sustainable approach to entrepreneurship is based on a long-term value creation that combines innovation, open co-operation with stakeholders, and engagement with the community. To properly implement the sustainability principles, it is necessary for the company to change its traditional approach to entrepreneurship and to recognize the key importance of issues such as job creation, value creation, environmental problems, community problems, the use of new technologies, legal limitations, and requirements of the State [11].

Some companies are aware of the importance of sustainable development and manage to get the image of a sustainable company into the public eye. A better image is then reflected by improved reputation, which can help companies gain a competitive advantage. In addition to improving the image, the use of sustainable development can also bring productivity growth to companies [12].

Based on the positive or negative reputation of the company, employees choose the company they want to work for, the investors choose the company they want to invest in, and the customers choose the company from which they buy the products or services.

In Slovak, major newspapers call sustainability a megatrend and claim that it will affect all companies, industries, and employees in the future and, at the same time, state that the approach that a company chooses to introduce sustainability will have a profound effect on its competitiveness or even its survival in the future.

The importance of sustainability and a sustainable reputation is also confirmed by surveys. In 2011, up to $67 \%$ of surveyed managers said sustainability was the key to gaining a competitive advantage. Another survey, in the same year, also explored the motivation of companies and managers to promote sustainability. Up to $41 \%$ of managers identified improvement of the company's reputation as the main reason for implementing the sustainability principles in their company [13]. Garberg also 
assumes that improving reputation is one of the main reasons for the implementation of sustainability principles [14].

There are several ways in which the company can achieve a sustainable reputation. The first and most progressive way is to apply the principles of all three pillars of sustainability in the company. In this case, the company should carry out these activities closely linked to the concept of sustainability, for example [1]:

- Operate as a green company, use the alternative energy sources and recycle generated waste;

- carefully select the material and use it as efficiently as possible without undue environmental or economic loss;

- Protect the health and safety of employees and treat them within the context of social justice;

- Accept the company as part of a wider community (local, regional, and global) and to try to contribute to its development, etc.

Even though many companies try to gain a reputation as a sustainable company, gain competitive advantage, and meet the demands of all stakeholders, only a few of them really fully apply the principles of all three pillars of sustainability.

Another way to improve reputation through sustainability is to create an image of a company that will gradually implement individual aspects and principles of sustainability in the future. In this case, the company can benefit from the competitive advantages associated with the image of sustainability, even if its principles are not widely used yet. Building a company's reputation on the road to sustainability can be managed if the company is really trying to fully implement the sustainability principles into its processes. Some companies, however, focus on building a sustainable reputation because they see it as financially beneficial and do nothing more sustainable than their competitors [15]. Some people have more natural distrust than others and they demand more interest and more effort from the company [16].

Today, company sustainability is the result of the long-term development of ethical business practices, meaning it is important to take care of socially responsible business in the company [17]. Sustainability was also defined by Bergman as a "systematic business approach and strategy that takes into account the long-term social and environmental impact of all economically motivated business behaviours in the interests of consumers, employees and owners or shareholders" [18]. Independent external resources that help to build a sustainability reputation include, for example, reputation indexes, sustainability indexes, certificates, independent reports on actual sustainability outcomes, etc. Each of the internal or external reputation builders has a different importance and can otherwise influence the views of customers and other stakeholders and, thereby, can subsequently, positively or negatively, affect the overall sustainable development reputation of the company [1].

Another tool for influencing a company's own sustainability reputation is corporate sustainability disclosure. This is voluntary information provided by a company that helps show legitimate business behaviour, educate and inform stakeholders, and influence their expectations. Corporate sustainability disclosure serves to build reputation by providing information about the company's environmental, social, and economic results to its stakeholders. At the same time, it also helps to reduce the risk associated with managing the reputation of the company [19]. If the company succeeds in convincing people to persuade stakeholders about their efforts to build sustainable growth and contribute to improving the world's conditions, it will also improve its overall reputation. If a company already has a strong reputation, in terms of sustainability, it can use the corporate sustainability disclosure to maintain it. The amount of sustainability disclosures and their range can affect the overall reputation of the company and, thus, provide it with a competitive advantage [20].

Sustainability helps the company reduce public pressure, increase public tolerance in the event of future problems, acquire new licenses, or attract new investors [21]. Acquisition of new investors can significantly boost the future growth and development of the company. Companies performing sustainability and social responsibility activities can positively influence their reputation, making 
them more attractive candidates for domestic and foreign investors. Companies that improve their reputation through the implementation of sustainability principles send a reliable and meaningful signal to investors, reducing their uncertainty and providing important information.

As has already been mentioned, sustainability brings together three basic aspects. Those are economic, environmental, and social aspects. The impact of the individual aspects of sustainability on reputation was studied by Leaniz and Bosque [22]. In his study, he found that the implementation of all three aspects of sustainability had a positive impact on the overall reputation of the company. However, the size of the impact varies.

According to the study, the economic aspect of sustainability has the biggest impact on reputation. The company should, therefore, address the issue of long-term and sustainable economic growth and value for all stakeholders to build a reputation when communicating with them. The economic aspect is followed by the social aspect. The initiative to address social issues, active participation and collaboration in the creation of cultural and social events, and the improvement of the social level of the community in which the company is located are ideal tools for improving reputation. At the same time, however, it is necessary for the company to communicate all the above-mentioned activities correctly to all stakeholders. According to de Leaniz and Bosque, environmental activities, such as recycling, the use of alternative energy sources, and the maximization of material efficiency, have the least impact on the reputation of the company.

Successful implementation of all three pillars of sustainability and gaining a reputation as a sustainable company can also have direct financial benefits for the company. There is a direct link between the market value of the company and its reputation, in terms of sustainability. Companies with a positive reputation in the above-mentioned area generally have a higher market value than companies that do not have such a reputation [23]. This fact can be explained, to a certain extent, by the higher willingness of foreign investors to invest in companies with a sustainable reputation. A company implementing sustainability principles gives all stakeholders, including the potential investors, the impression that they are effectively trying to build up their reputation. At the same time, however, it must be remembered that not all companies that have a positive reputation, in terms of sustainability, have achieved it by a complicated implementation of the principles of all three aspects of sustainability. Some have succeeded in gaining it through clever use of publicity. In this case, a company perceived as a sectoral leader, in terms of sustainability, does not necessarily have to outperform its competitors in any of the three aspects of sustainability [1].

\subsection{Processing of Our Theoretical Framework}

In order to perform our research, a theoretical framework based on corporate reputation was examined, with the aim of producing a knowledge base for our research. We have focused our effort on issues in the online environment, which, according to the theory, have a significant impact on an organization's reputation. Other theoretical concepts helped us to analyze the gathered information, e.g., semantic analysis or the common scientific method of content analysis. Existing theory about sustainability showed us the importance of analyzing these issues from wider point of view. To be more specific, this theory tells us about ideal processes and about how they could and should work together for complex positive synergy. When we incorporate this point of view into our analysis, we are able to analyze and evaluate these issues in a more critical way. We have also used theory about sustainability, in this discussion, to provide recommendations considering sustainable online reputation.

\section{Materials and Methods}

As the main method, we chose a content analysis of available online information. We focused on four strong brands from the automotive industry. Three of them were selected because they have production plants in Slovakia (VW, KIA, PSA). We chose Toyota for their long-term reference power in the industry. We deliberately did not include brand Škoda in the analysis, mainly since it has a very strong position in Slovakia. It is the best-selling and most popular brand of passenger cars on the 
Slovak market [24]. That's why we chose the brand of the company that also includes the Škoda brand, specifically, the Volkswagen Group.

The analysis focused on the three main information levels available online, as follows: (1) Information about the brand from the main official source company (brand), meaning the main brand websites of their European offices; (2) information about the brands from their official sources in the Slovak Republic; (3) information about the brand from diverse sources in the Slovak Republic, meaning articles on automobile sites, reviews and comparisons, customer responses, mentions in newspapers and newspaper websites, and social network groups.

By applying this form of analysis, we monitored whether brand management is consistent from the primary European source, through the local Slovak market, to the perception by the public and customers.

The reasons why we chose a perspective from the Slovak Republic are the following: (a) This is the country where we live, so the analysis of the market is important for us; (b) Slovakia, as part of the European Union, is a good example of how rigorous and perceived global automobile brands, in the online area, are at the regional level; (c) there are currently VW, KIA, PSA and, the latest, Jaguar-Land Rover production plants in the Slovak republic and the country produces the most cars per capita. This fact significantly influences the Slovak public. Automotive companies are the key employers and are doing several CSR activities [25]. (d) The Slovak economy is growing, as is the purchasing power of the population and the purchase of new cars is particularly dynamic. As a result, the Slovak customer is relatively attractive for global brands [26]. (e) Slovakia has been following the worldwide trends of online communication, the growth of social networking, and online shopping.

We have performed a thorough content analysis of online sources. We briefly reviewed main official web sites and continued to a more thorough analysis of the Slovak online environment. We have checked and analyzed information from the following areas:

1. Official corporate websites, European Union versions: How is the brand presented to the public; Main branding claims and slogans; Main proofs of brand success (historically significant events, various awards, partnerships, sponsoring, etc.).

2. Official Slovak websites: We focused on the same aspects as in the previous point and we also tried to find significant differences between brand presentation on the EU and Slovak levels.

3. Social media usage, official brand level, Slovak Republic perspective (Facebook, Instagram, etc.): Major types of content and posts.

4. Major online car and motor magazines and newspapers, Slovak Republic perspective: Tests results; Comparisons between analyzed brands, brief information, etc.

5. Social media, public level, Slovak Republic perspective: Reaction of Slovak consumers towards the analyzed brands; Consumers' opinions (about brands, products, services, etc.).

6. Online discussion forums (car and automotive topics; buying advice; fan clubs; repairs and issues advice, etc.), Slovak Republic perspective: Discussions of major topics; consumers'́ opinions.

After we searched and found relevant online sources, we ordered them into one of the six above-mentioned areas. This was done for each brand analyzed. Online reputation can have a significant influence on automobile customer behaviour. The level of marketing activity, customer reactions, or the activity of influencers can have an effect on the company's public relations. To assess the reputation management condition of the studied companies, two control groups of online environment information were used. The first control group (Sections 4.1, Sections 4.2, Sections 4.3 and Sections 4.4) is composed of the official sources of consumers' opinions concerning the marketing activities. The second control group (Sections 4.5) serves as an information source for the sentiment analysis. The level of online reputation was determined based on the two control groups and the basic elements of successful online reputation management were stated.

For a deeper review of the context, we have used the methodology called sentiment analysis or opinion mining. It can be defined as a quantification of subjective content, expressed in textual form, 
to determine the attitudes of the commentator or the writer with respect to the given topic. It is one of the oldest and frequently used methods of reputation measurement. In general, it is possible to say that sentiment analysis is the goal of determining whether a speaker or a writer has a focus on a particular topic or the overall conceptual polarity of a document. The approach can be the judgment or assessment of a particular person, the emotional state of the author, or the intended emotional communication, which is the emotional effect that the author wishes to create with the recipient [27]. The methodology has a wide range of application areas, like services, the film industry, consumer goods, online impact assessment, social media monitoring, product, service or brand monitoring, stock price forecasting based on the online evaluation, cyberbullying, etc. Among its priority tasks are the identification of subjectivity, orientation, strength and wearer's sentiment, classification of emotions, sarcasm detection, or other different comparisons [28].

We used the Google search engine to get the information. We used anonymous access so that the results are not influenced by the search history of the specific IP address. We focused only on the main results for the given brands, namely the first 15 results. We did not take sponsored links and advertisements into account. We chose the following procedure when creating sentiment analysis: Firstly, we needed to avoid distorting results by preventing the personalization of the search, for example, by setting a neutral VPN. We chose the Google web search engine because of its frequent use among internet users. From a conceptual point of view, searching was done in one day to maintain the continuity of the sentiment analysis data. Search keywords were official names of automobile companies, i.e., Volkswagen, Toyota, KIA, and Peugeot. For the most relevant results through sentiment analysis, a search category of news articles, that has been ranked hierarchically, was selected. In the analysis, a list of news articles in the Slovak market was created for the reasons given above. At the same time, all direct connections to automobile companies were omitted, i.e., official company home pages and sponsored news articles. Considering sentiment analysis, we used the free online DanielSoper Sentiment Analyzer [29].

The aim of the article is to present the results of the analysis of the online presentation of VW, KIA, Peugeot and Toyota brands primarily on the Slovak market, secondary in the Central European market and in a global context. Based on the results of the analysis, offer recommendations on sustainable brand management in the online area into the discussion.

\section{Results}

In this section, we will gradually present the results of our analysis. All information on the Volkswagen, Toyota, Kia, and Peugeot brands is available online. Introduced information will be from the position of the European Union and, possibly, the whole world. Subsequently, we focus more closely on the Slovak perspective. In the conclusion of this section, there is a sentiment analysis. We took the mentioned brands into consideration and the analysis was also carried out from the perspective of the Slovak Republic. We dealt with two major groups of results as follows: (a) Results from content analysis and (b) results from sentiment analysis. Considering results from content analysis (a), we have decided to present them in the form of a comprehensive explanatory text. Considering the results of sentiment analysis (b), we present them as values, graphically, with brief explanatory texts.

\subsection{Volkswagen Brand}

Volkswagen acts as a company that wants to build its future as an industry on innovation and socio-ecological thinking. It presents itself as the largest employer and, today, it employs more than 627,000 people [30]. At the same time, it covers other automobile brands such as Bentley, Audi, Seat, Lamborghini, Ducati, Porsche, and others [31]. The company focuses on a wide portfolio of cars. They describe themselves as the largest carmaker, with production figures reaching up to 10.3 million. The customer and public view of the company and its products is significantly more negative because of the 2015 emission scandals, which have caused, among other things, a decline in the reputation of the company and a $20 \%$ reduction in car sales. [32] They also want to become the world leaders in 
production [33]. After the scandal, VW's consumer-friendly recommendations in the online environment dropped by $67 \%$ and negative recommendations increased by almost $2000 \%$ [34,35]. Nowadays, the company is gradually recovering its reputation and regaining the trust of its customers. On the other hand, Volkswagen is involved in the socio-environmental area of environmental improvement, which is also linked to innovation in the manufacturing sector. By 2020, they want to continue to produce innovative electric cars that will protect the environment. For the country's development, they help the residents by investing money in education, science, health, and sports [36].

The World Rally Championship (WRC) is a championship with a continuously growing audience. One of the sponsors of the championship is Volkswagen. By using the possible visibility, due to a very high audience, the company raises its brand awareness. In 2016, more than 700 million viewers watched the championship on TV, with the WRC broadcasted on 155 television stations with more than 17 million viewers on the Internet channel. Four million spectators attended 13 championships. The 2016 World Rally Championship had more than 2.4 million Facebook likes, more than 250,000 Twitter followers, and 310,000 Instagram followers. According to official sources, even though it won every championship since 2013, Volkswagen decided not to take part in the 2017 WRC, due to the development of a new car. Other sources, however, say that the reason why Volkswagen did not participate in the championship, even though they had a car prepared for the season, was the above mentioned Dieselgate scandal [37-39].

The World Car Awards (WCA) is a program initiated and organized by automotive journalists from around the world. The program's goal is to ensure that valuation is carried out with the highest degree of objectivity, credibility, and integrity. In the most recent results, the Volkswagen Tiguan was placed in the top ten. Interestingly, the Volkswagen Passat placed in the top ten in 2015, but in 2016, their model did not make it on any front line. We presume that this absence was due to the emission scandal that has substantially altered the credibility of the brand [40].

Volkswagen's commitment to become the industry's most sustainable company was confirmed by the Dow Jones Sustainability Index (DJSI). Just a week before the scandal broke out, DJSI declared Volkswagen the world's most sustainable carmaker. The reputation institute measured the company, on a continuous basis, in more than fifteen countries. This continuous reputation measurement service (provided by The National Tracker) enables companies to see the immediate impact on their reputation anywhere in the world. The month after the scandal broke, the impact on Volkswagen's reputation was drastic [41].

Volkswagen Slovakia has been operating on the Slovak market since 1991. It is the largest and longest-running automotive producer in the modern history of the Slovak Republic. Cars are produced at the Bratislava, Martin, Košice, and Stupava plants, currently producing the Volkswagen Touareg, the Volkswagen Up! and the Volkswagen e-Up! It currently employs more than 12,700 people. In 2016, the company produced 388,687 units of vehicles and earned a pre-tax profit of 234.1 million euros [42]. In 2013, Volkswagen Slovakia won the Factory of the Year International Award. The Bratislava plant is the best factory in Europe. Bratislava won first place in the category of excellent large-scale production [43]. In 2016 it was awarded the 2016 Investor of the Year. This was a new award by weekly magazine TREND presented for the first time in 2016, in cooperation with KPMG as a project partner. Based on an innovative staff transportation service, it received an award for the Innovative Action of the Year for Bus Management. Volkswagen Slovakia earned first place [44].

In 2016 Volkswagen won the Best employer award in the production and industry category. Another interesting aspect of Volkswagen's reputation in Slovakia is the fact that many Volkswagen owners, more specifically 31,634, are on the Facebook social network, registered in the "VW—Club Slovakia" group [45].

In the interest of its own prestige and an increase in the expertise of its employees, Volkswagen Slovakia has established a privately-owned technical secondary school—the Automotive Dual Academy. As part of the study, as well as in the company, pupils are introduced to the most advanced technologies and the industry's top working environment. The main benefits are practical lessons, 
which make up $70 \%$ of the tuition, business scholarships, and an internationally valid bilingual German certificate of professional competence. The study is free of charge [46].

\subsection{Toyota Brand}

Toyota is considered to be the world's largest car maker, in terms of sales and the number of units manufactured, and is constantly in competition with Volkswagen in these two categories. In 2016, Toyota's global sales rose by only 0.2 percent to 10.18 million vehicles [47]. The views of the professional public are reflected in various awards and tests. In the most renowned TÜV institute reliability review, 14 Toyota models have been ranked among the top ten most reliable models across the different categories, which is the most of all carmakers. In addition, according to the portal yourmechanic.com, it has been placed at the forefront of the list of cheapest spare parts producers [48].

According to official staff satisfaction surveys that Toyota has done every two years, satisfaction has been rising or stagnating. The satisfaction of administrative and technical staff reached $77.2 \%$ in Japan and $76 \%$ in other countries, with the most satisfying being the quality of work. Employees on production lines were satisfied at $71.9 \%$ in Japan and $72 \%$ in other countries, with wage conditions being the most common reason for satisfaction [49]. Employee satisfaction can also be tracked through unofficial internet resources, such as the indeed.com portal. Toyota's overall rating from its employees reached 4 out of five, with the culture (score 3.8 out of 5) and benefits (score 3.8 out of 5) being the most satisfied areas within the organization [50]. The score is above average in both cases, but there is still the potential for improvement.

On its official site, Toyota mentions several awards including the Kelley Blue Book's Best Resale Value Award. This award is awarded to automobile companies for the so-called "resale value", which is the after-sales value of the car, i.e., the value for which the owner can sell the car in the future. In addition, Toyota boasts the highest number of Top Safety Pick + awards from all car manufacturers [51].

As for the brand, Toyota is ranked the 7th worldwide in the world's top ranked list in a global ranking of all world brands, not just cars. The Toyota home page includes, among other things, the award for the most durable cars, among other manufacturers such as Ford Motor, General Motors, or Nissan. However, Toyota is not among the best-selling automotive brands in Slovakia and in the first half of 2017 it was in tenth place in terms of sales [52]. Toyota is not a producer in Slovakia and it does not employ a large number of people, so it is not possible to reliably focus on reputation from the employee's view.

All analyzed portals inform about Toyota's activities, what strategic steps it takes and recall its innovative efforts especially in the field of alternative propulsion that except for electro mobility, focus mainly on hydrogen propulsion. In addition, the latest models and awards that Toyota has won in various rankings are also mentioned. All the articles are positive and Toyota is denoted as the legendary, the greatest, the most valuable, etc. Even in articles that have a negative sentiment, such as car issues and calling events, Toyota is not portrayed negatively. It can, therefore, be said that even the Slovak media are helping to build a positive reputation of this automobile brand [53-57].

Another reason is the geographical location. People in Slovakia have a very long and close relationship with the Czech Škoda brand, which is also reflected in sales rankings, where Škoda models have long-standing lead positions. The Slovaks also have a higher level of confidence in another Central European car maker, Volkswagen, and its models and believe in German precision. Japanese design is very specific and buying Toyota is a matter of taste. Those who decide to buy Toyota choose it especially for its name as the most reliable car manufacturer in the world. In articles and programs, journalists devote themselves to specific models and not just to the brand as such. They agree that most Toyota models being made are based on the overall ergonomics of the vehicle and the comfort, reliability, quality, and safety of passengers [58,59].

Every two years, Toyota organizes a Motor Show in which it also participates and shares information about new vehicles with the world. It publishes information about the location of the event on the website, as well as photos and statements. In 2015, the number of visitors to this 
show was 812,500 , which is a decrease compared to 2013, but Toyota can still reach a large number of potential or current customers this way [60]. Toyota is also active in Toyota Gazoo Racing motorsports and shares its achievements on its official website, on social networks, and on its news websites [61]. It also organizes the annual Toyota Dream Car Art Contest where children from around the world express their ideas about the future of mobility. According to official website data, more than 800,000 participants have entered this competition [62]. The results are presented in a similar way as in the case of motor sports. Another part of reputation management is social media activity. According to the official Toyota global site, Toyota uses 3 social networks, Facebook, Google+, and YouTube. Unfortunately, the Google+ profile link is inactive [63].

\subsection{KIA Brand}

The Kia brand is ranked first in the world's most trusted brands, according to a JDPower-based car satisfaction survey. The survey is based on 12,000 owners of 1-3-year-old cars. The evaluation of the survey shows that Kia is one of the brands that preceded "premium brands" in reliability [64].

The effort of the Koreans is to achieve a technical quality that is equal to the American one. At the moment, KIA is even compared to the quality of the German Volkswagen. Specifically, the quality of the Kia Ceed is highlighted. This was presented by the well-known English motor show Top Gear, which compares and tests cars of different brands and origins. Top Gear also compared the several of the Kia brand's car models. The best models were the Carens, the Ceed, the Pro-Ceed GT, the Picanto, and the Sorento, with 7 out of 10 ratings [65].

Globally, Kia uses online communication channels such as Facebook, Instagram, Google+, Pinterest, YouTube, LinkedIn, Twitter, and KiaBuzz to communicate and reach protentional customers. Locally (Kia USA, Kia SLOVAKIA), it also uses separate accounts or dedicated websites for better visitor reach. An example of this may be the separate pages for the factory in Slovakia and for the presentation of the brand, products, services, and other events and requisites. There is also a separate representative page where Kia represents its brand and explains its aspects [66].

The world sees the Kia brand through world-class sporting events that aim not only to promote and support the event, but also its brand. Since 2002, Kia has become the main sponsor of the Australian Open, where it has supplied more than 100 vehicles designed for top tennis players, VIPs, and others. Kia promotes its value, "The power to surprise", through world-renowned tennis player Rafael Nadal, who has been the global Kia ambassador since 2006. It also increases its brand awareness through its marketing activities and FIFA stadium advertisements, where Kia has become the official car sponsor for the 2007-2020 seasons. Another event that contributes to brand awareness is UEFA EURO, the largest football event in Europe. Kia has become the top partner of the event for the 2006-2017 period [67].

In recent years, Kia cars have gained a stronger position on foreign markets. In the Initial Quality Study (ISA), Kia had the least number of defects in the first 90 days of use. Kia even beat brands like Porsche or BMW [68].

The Kia brand in Slovakia is mainly associated with the Žilina plant, which was the first European production plant for the company. It created more than 10,000 new jobs in the region [69]. Currently, Kia Motors Slovakia is one of the three largest producers and exporters in Slovakia. Since the start of mass production in December 2006, the plant has manufactured more than 2.5 million vehicles [70]. In the 10 years since its inception, Kia Motors Slovakia has become one of the most important automobile manufacturers in the Slovak Republic. The Žilina plant manufactures cars for an ever-expanding network of European dealers. The company is still trying to improve its name in Slovakia, especially by proving that they are not "Korean" cars but, on the contrary, cars with Slovak spirit and quality. The Kia brand has won several awards in Slovakia, for example The Slovak National Quality Award in 2016 [71], 3rd place in the ranking of the biggest companies of the Slovak Republic, conducted by Forbes magazine, and [72] the Award of the City of Žilina for assistance in the development of the city and the region [73]. 
These awards have helped the brand to increase brand awareness (e.g., increased sales). This was most reflected in the new generation of the model Sportage, which in 2016, significantly increased in sales and the became the staple model of the production. This model has also won several international awards for quality and design and has also excelled in the long-term reliability test [74-76].

Kia has created a Facebook site where everyone can add their complaints, queries, and views that the management will try to solve (more info about the employees is in the third part of the analysis) [77]. The company in Slovakia also started a foundation named the Kia Motors Slovakia Endowment Fund in the Pontis Foundation, which seeks to support the development of the Žilina region. It also organizes donor activities to support social issues [78]. The Kia Motors Slovakia Foundation also helps with philanthropic activities to support sports activities, develop regional education, or promote volunteering with partner non-profit organizations [79].

\subsection{Peugeot Brand}

In 2014, the PSA group made significant progress in improving efficiency, competitiveness, and reducing structural costs. All of that helped it to raise its Moody's Investors Service rating from B1-PD to Ba3-PD, which had a positive impact on their global reputation [80]. Their reputation is also influenced by the sporting events that Peugeot participates in and prepares. After the PEUGEOT 2008 DKR won the Dakar Rally in January 2016 and, later, the Silk Way Rally, PEUGEOT started the 2017 rally-raid season with the new PEUGEOT 3008 DKR rally special, which was born out of the PEUGEOT 3008 SUV [81]. It also engages in ecology issues. Its quality is confirmed by the awards received over recent years. On the 18th anniversary of the International Engine of the Year Awards in Stuttgart, the international journalistic jury awarded the three-cylinder PureTech 1.2 engine with the title Motor of the Year 2017 in the 1.0-1.4 L category. Peugeot won this award for the third consecutive year. It also won this category in 2015 and 2016 [82]. Peugeot also received other awards, including Mid-size SUV of the Year 2017 (Peugeot 3008) [83] and European Car of the Year 2017 (Peugeot 3008) [84]. Peugeot's current goal is to draw attention to the fresh, inspiring, and striking expressive design of its 3008 model [85].

However, the Peugeot brand has built the reputation of cheap and reliable cars by regular and continued participation in the most demanding endurance races in the world, including the famous Rally Paris-Dakar (today known as the Dakar Rally). The Peugeot factory team was able to win this prestigious race four times in a row in the years 1987-1990 and the last times were in 2016 and 2017. Today, it is the world 's second most popular motoring event, with a total broadcast time of $1200 \mathrm{~h}$ on 70 stations in 190 countries [86].

The overall perception of the Peugeot brand surely changed with the acquisition of Opel and Vauxhall in March 2017. What were the benefits? The acquisition of Opel and PSA brought the PSA group into a market segment where it could not operate and profit previously, as well as making it the second-largest car maker in Europe. This acquisition has been particularly important in the field of technology, in which the PSA group was lacking. The benefits of these technologies have greatly helped satisfy customer needs in the German market, where Opel has a long tradition.

Most of Peugeot's reputation management activities in Slovakia are made under the PSA Trnava production plant, which creates almost 3500 direct jobs and is one of the most technologically advanced plants in the PSA Peugeot Citroën group. Regarding the energy consumption of a manufactured vehicle, it is among the best carmakers in Europe. It provides many benefits to its employees, for example, reimbursement of sports activities by the civil association ASPSA or operative leasing of vehicles for employees. Using the $2 \%$ tax donation, it sponsors a number of institutions. Peugeot organizes the Christmas markets connected with the St. Nicholas holiday to the public in Trnava. It also collects money for charity, where it adds two more euros to every euro collected. Since 2017, it has launched the fourth work shift, which represents 800 new jobs. Since the crisis in 2010, it has not dismissed a single employee for organizational reasons. A total of $98 \%$ of the staff members have a contract for an indefinite period, which provides them with job security. PSA Trnava is also leading education support projects in Slovakia called "Kampus povolaní" and "Vyhrňme si rukávy". The 
brand is also presented as a "Slovak sports partner". Other activities include Peugeot Tennis Day [87]. It also creates partnerships outside of the sports sector. Interesting is the cooperation with the Slovak National Theater, to which it has provided 6 cars of various types. It was also one of the major sponsors of the Slovak Presidency in the EU Council [88].

\subsection{Results of Sentiment Analysis of Selected Automobile Companies}

Based on the established methodology, 15 search results of online content for each brand, dealing with Volkswagen, Toyota, KIA, and Peugeot, were selected. Sentiment values for individual articles were quantified in the range of -100 to 100 using the DanielSoper free online Sentiment Analyzer [29]. For the purpose of comparing the results, the individual sentiment values were grouped from the worst to the best (left to right). The following figure (Figure 1) shows that, in selected automobile brands, the values of online sentiment are evenly distributed (at first sight, there is no negative or positive sentiment). After a detailed look at the results and by plotting the moving average of the values obtained, we can state the following:

(1) Toyota has the best online reputation based on sentiment analysis (dotted orange line). Up to 11 of the 15 search results had positive sentiment values. The total highest values are shown in Table 1.

(2) In the results of the analysis, KIA appears to be significantly negative and low in sentiment values. However, after averaging the results, its overall sentiment values are better than the Volkswagen brand. This phenomenon can be explained by four high values with the best search results.

(3) In the context of the surveyed data, Volkswagen was the worst, especially for the significant negative sentiment analysis results.

(4) Peugeot's overall results represent a balanced distribution of positive and negative sentiment values.

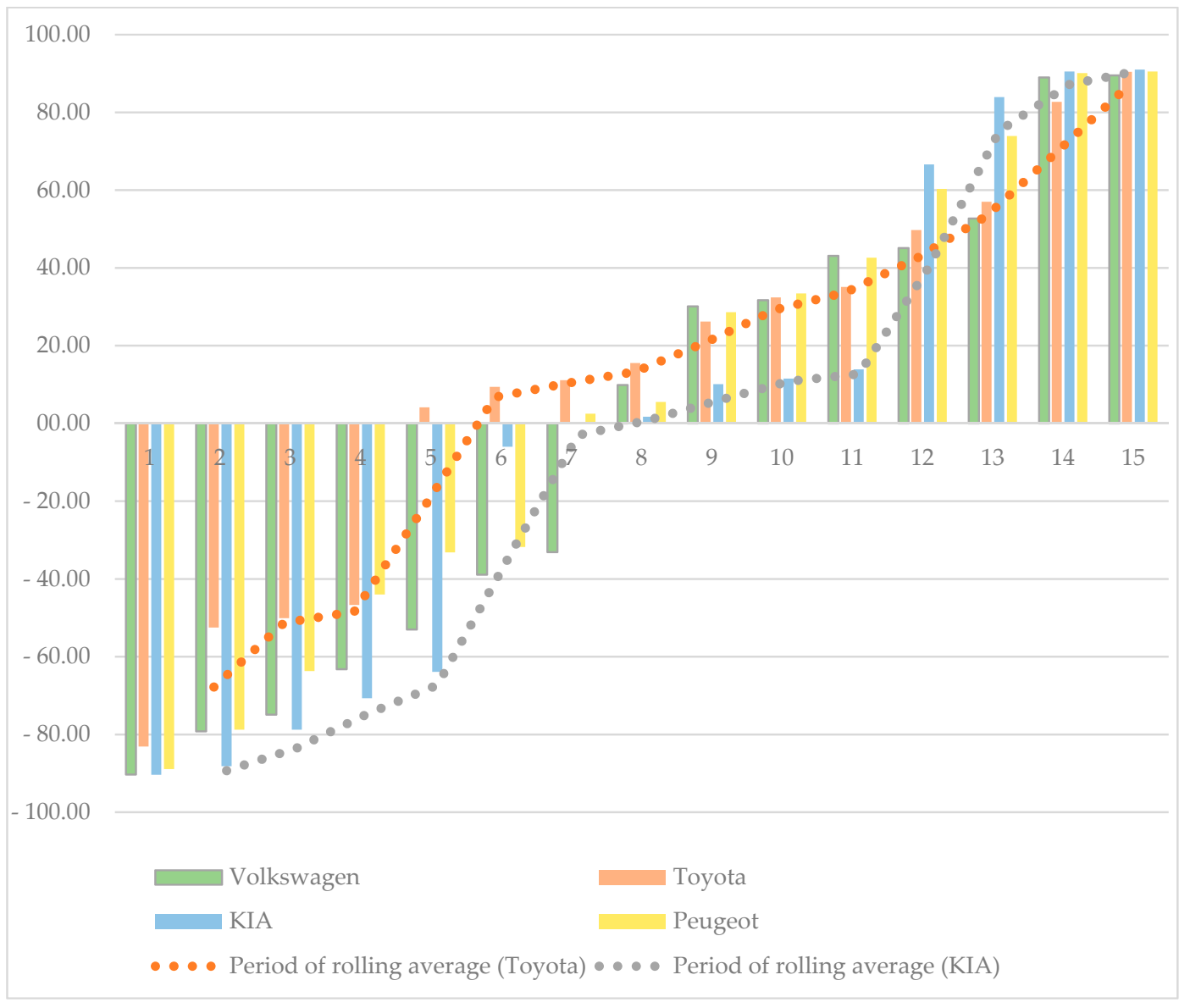

Figure 1. The sentiment analysis results of the four automotive brands. 
In the following table, we can see the average values obtained through the sentiment analysis of the above-mentioned brands. Toyota has the best reputation, followed by Peugeot, Kia, and Volkswagen. However, the results are limited by the above-mentioned data. This is mainly concerning the Central European market and research within the territory of the Slovak Republic. The Škoda automobile brand, that has a strong awareness from customers in the Slovak market, was omitted.

Table 1. The average results of the four automotive brands.

\begin{tabular}{ccccc}
\hline & Volkswagen & Toyota & KIA & Peugeot \\
\hline SUM & -41.50 & 181.20 & -20.90 & 87.00 \\
AVG & -2.77 & 12.08 & -1.39 & 5.80 \\
\hline
\end{tabular}

\section{Discussion}

\subsection{The Most Important Factors for Sustainable Online Reputation (Positive and Negative Factors)}

The Internet has changed reputation. What was once private is now public. What was once at a local level is now global. What was once temporary is now permanent and what was once trusted is now unreliable. These changes can be explained by the fact that Internet technology has been directing human interactions [89]. Understanding the unique relationship between technology and online culture is the key to understanding how to manage online reputation. Failure is certain for those marketing managers who apply offline techniques to online reputation or use offline prerequisites to solve online problems. Instead, a competent marketing manager must understand the cultural and technical differences between the offline and online worlds to effectively protect and improve the online reputation of their company.

Based on the results of the analysis, we have grouped the most important factors, that can negatively or positively influence a brand's reputation, as follows:

Positive reviews: We include professional articles as well as amateur reviews because readers believe these articles more than ads. From a general point of view, this includes the company's social networking, media, internet advertising, banners, etc. This is information from relatively formal sources that the public finds when searching for information about the brands in question (or specific products). From our point of view, the management of the information structure is the key. It must be clear what the brand (or the specific product) promises to the customer on the main website. Other information must be consistent with this promise. It is a key principle that applies to the brand in general, not only in the online space. This principle has been described very well and in detail by, for example, K. L. Keller [90]. The Internet environment is extremely dynamic and more complex and more frequent checks that communication is consistent are necessary.

Negative reviews: Which include dissatisfaction with the quality of service, the spread of untrustworthy stories that customers may find, and repeatedly spreading negative comments. There is the need to defend and to provide truthful information and, here, the truth means that the problems are real and need to be addressed. Brands must communicate openly about them and, if it is appropriate, confess the error, apologize, and offer an adequate solution. Very good communication management of such crisis was seen in the Toyota case. It was based on alleged technical failure of certain models in the US market. Toyota immediately offered a solution, they were transparent, and they did not let the media and the public doubt their good intentions.

Awards also contribute to the brand's reputation. This involves engaging in available local competitions and assessments. These often have their own communication campaign built in. Each award has the potential for a relatively strong PR effect. Additionally, the local public tends to better understand local awards (e.g., National Award of the Slovak Republic for Quality and National Award of the Slovak Republic for Social Responsibility).

Philanthropy and CSR: Which includes supporting projects that need the most support, dual education, and foundations (areas include technical education, foreign language, transport education, 
and engagement of disadvantaged groups of people). Companies also build their reputation through charity projects and engagement in volunteering. The most important part is the ecological trend, which is presently the basis of business because, even for the sake of the legislation, businesses must work with regards to the environment. Again, there is an important local context when companies associate their brand with activities that have a direct impact on specific communities.

Customer care: Customer care is necessary for maintaining customers and referring to potential customers. Care is focused on customer inquiries, surveys and feedback, sales promotion, and other services. The online space also provides online services, like YouTube videos or live chats with customers. It also includes consulting, solving specific problems, and helping to select products or accessories. It is a relatively powerful tool as people spend more and more time in the online space. The reaction time is essential, for example, the response in the live chat is expected to be instant.

Sponsorship: It is important to choose the right partners and maintain good relationships with them. It is also necessary to take into account the local situation, for example, in Slovakia, KIA sponsors the football club (MŠK Žilina) in the city where the production plant is located. Appropriate sponsorship can achieve a synergy effect when the sponsor brand is displayed in a partner's online presentations.

Employee satisfaction has a very positive impact on the company's environment, helping the company gain potential employees and customers or business partners. The culture and philosophy of the business helps to create a positive brand image. Corporate culture, its values, and the positive feedback of employees need to be communicated online as well. In Slovakia, current companies experience a lack of workforce [91]. Proper communication of these aspects online can significantly improve recruitment marketing.

In all the cases we analyzed, we have recognized that, for good online reputation, it is appropriate to present factors such as tradition, quality, ecology, and innovative technologies. Tradition points to a good previous experience. Quality and innovative technologies appeal to the customer's rationality. In general, they tell customers to decide on a product that is safe, technologically advanced, and reliable. Ecology also appeals to the rationality of customers, most often with regards to low fuel consumption. However, it also appeals to their responsibility for the environment, their lifestyle, and social attitudes.

As far as crisis communication is concerned, we find it very important. As an example, let's recall the Dieselgate of the VW Group. Various problems can turn into scandals. In this case, it is particularly necessary to have proper crisis management that will also accentuate the online space. We also noticed that there is often an online space (most often on social networks or different forums) where there are statements of dissatisfied employees or customers. The form of brand reaction is questionable. The proper and correct approach seems to be monitoring all these negative reactions and then responding in particular via standard online media (or methods and procedures). A direct response to a specific comment is also a powerful tool. Its form is essential. It should be open and should highlight the principles of corporate culture and call for action.

\subsection{Managerial Implications}

From the point of view of the management, it is important to manage the reputation in the online environment so that it is consistent with the organization's branding and public image [92]. It is equally important, in the sense of online reputation, to manage the image of corporate culture and its core values. Concerning the concretization for use in management practice, it is extremely important for the entire online reputation management to be understood in terms of the concept of sustainability $[93,94]$.

In large enterprises, it is advisable that specific job positions should be specialized in the management of online reputation and, of course, in line with overall marketing and PR. For small and medium business, it is essential for marketers to also focus on online reputation management. This is, therefore, a matter of correct time management. For some small businesses or small organizations (voluntary associations, non-profit organizations, etc.), it may even be more appropriate for online reputation management to become the dominant marketing tool for them. 
A critical role is played by the accessible technical (ICT) infrastructure. Extremely dynamic developments in hardware, software, as well as the expanding availability of the Internet, enable small and medium-sized businesses to participate in modern and efficient solutions. This is especially true for online automated software tools. The ability of organizations to use technology, that is available in the right way, is crucial for their survival in the marketplace and for their strategic competitiveness. For example, according to Mikalef and Pateli's research findings, "IT-enabled dynamic capabilities seem to support the evolutionary fitness of the firm by enhancing agility in terms of market capitalization and operational adjustment, which in turn leads to competitive performance" [95]. In accordance with authors quoted, we also note that the current environment is dynamic and turbulent. Sustainable solution is demanding and must consist of a complex of mutually complementary processes and activities.

Presently, the ability to respond quickly is critical for companies. Modern technology significantly contributes to a competitive advantage. Semi-automated or automated systems, which are designed to browse web sites, forums, and social networks can categorize the information found as positive, negative, or neutral. We are talking about specialized tools with artificial intelligence elements that use optimized search and Big Data principles effectively. We think that the human factor is currently irreplaceable. The manager must define the concept and, ultimately, decide how to proceed. On the other hand, the use of the available tools makes the process more precise and faster. Even a small business or an individual can use available online tools to track reputation. It should be noted, however, that this will bring relevant results primarily in English. More advanced systems are, of course, relatively expensive, but they can deliver more accurate and detailed results. They can partially predict development and bring realistic recommendations. They are suitable for some medium and large businesses. The positive thing is that the technology used by the advanced tools is becoming cheaper over time, so even smaller businesses can afford them. Similar sentiments were also expressed by Mikalef and Patel, whom we mentioned above. They said that the efficient use of available ICT can make a major contribution to organizational agility, which means that the company is able to "address unexpected changes that arise in the business environment by responding rapidly and exploiting changes as opportunities to grow and prosper" [95].

Mass use of ICT accelerates our lives, but also accelerates the spread of negative news. This means that the company must ensure that adequate response to a negative situation is as fast as possible. The same is true for positive reactions. A specific complaint or customer dissatisfaction expressed on a social network can be solved relatively quickly. Main success factors of complaint solving are the following: The company is interested, wants to provide a remedy, and provides a solution (ideally already with a positive customer response). However, if the negative aspects are picked up by the media and spread rapidly among the public, it is necessary to proceed with crisis management and consider each step thoroughly. However, the same principles apply here and the reactions must not be too late. The absence of a response or unnecessary prolongation of communication can also be perceived negatively and contribute to the escalation of the problem into a crisis. Negative information related to the company's products, in addition to quickly capturing such information, must be aimed towards providing virtually immediate action (or correction) in production and public communication. We have already talked about some examples. In terms of positive information and customer feedback, it is also necessary to promptly evaluate the situation and use it in production processes and marketing communications. Such a rapid reaction to positive customer responses has the chance to increase business performance by increasing revenue and the number of satisfied customers.

Companies must implement the management of online reputation into their corporate strategy if they want to efficiently survive and prosper. This should be mainly reflected in the form of a clear inclusion in the organizational structure. The main tasks of employees dealing with reputation management are the following: (a) Analytical activity. Its goal is to get up-to-date information on the current state. This information is critical to management decision making. In practice, this is an online space analysis that focuses on actions and the level of competitors' online reputation, actively 
searching for places where customers and the public express their opinions on the company, brand, or product with regular measurement of online reputation and comparison with competitors. (b) Design of the online space tactics. The concepts must follow the overall strategy, communication strategy, or image of the company. The attributes should include the online environment, for example web sites and corporate social networks. The concepts also incorporate an effective and purpose-based analysis of the information obtained (as described in the previous point). (c) Analysis of current possibilities in online spaces, analysis of customer behaviour in online spaces, and analysis of the trends. This task is about determining which tools and platforms are currently appropriate for the company and which are not. It is a targeted and continuous analysis of customer behaviour. In general, this activity focuses on answering questions including which websites customers currently prefer; which social networks are being used more and which less; which social networks are preferred by the target group; which way of communication is suitable for the target group; where it is necessary to proceed in the same way as the competition; and where it is possible to distinguish our company from them.

When carrying out these activities in practice, large and some medium-sized companies assign them to separate organizational units. Small and some medium-sized companies will only deal with them partially, according to their capabilities or intuitively. However, they should take into account all three of these framework categories $(\mathrm{a}-\mathrm{c})$. The possible solution of full or partial outsourcing is available to all the companies on the market

\subsection{Limitations}

From the point of view of possible limitations, it is necessary to point out the limitations of our research, especially the availability of data at the time of the research itself. However, we consider it necessary to state that the resulting comparisons and formulated interpretations provide a realistic, up-to-date, and comprehensive view of selected representatives of the automotive industry and their online reputation on the analyzed market.

A critical tool in today's online environment is SEO (Search Engine Optimization). It is a dynamic tool as it adapts to the current situation. The goal of using this tool is to make well-optimized sites appear in more prominent search result positions. We also consider this to be a limitation of our research, as the state of the examined online environment is influenced by the quality of SEO. We have tried to overcome this aspect by looking at information from lower search result levels or by doing targeted searches (e.g., discussion forums). The SEO factor is significant, since when searching, most people especially take into account the first results found.

Another limitation is that we mainly focused on the environment of the Slovak Republic. The situation will be slightly different in other countries. Slightly, because the online branding system of those brands is oriented to larger regions (e.g., Central Europe or the European Union). Local specifications must exist in each country. For this reason, we consider the Slovak market a suitable example.

\section{Conclusions}

Reputation management can be considered effective if it is part of an organization's strategy as such and is reflected in the core values or principles governing that organization. The analysis has shown that such reputation management is successful.

For successful and sustainable reputation management, several elements are necessary, as follows:

Use what the public uses (modern technologies, the online environment and its management). It is inevitable to work with what consumers work with. Good examples are technological devices, such as smart phones, and software platforms, such as Facebook.

Be where the public is (sponsoring, naturalization). There is a significant potential in very precise targeted communication (PR, advertising, etc.). The first necessary step is proper consumers' segmentation. The second is a comprehensive analysis of effective ways of how to effectively approach 
them. The third is analysis of potential partners who can help to approach the segments more directly (e.g., sport events).

Continuous self-present to the public (news releases, press releases). Brand awareness is the first necessary step to get to the higher levels of the branding pyramid. The public must know about the brand. There is also a huge opportunity to use opinion leaders to present the message (or image) in more efficient ways.

Prevent stagnation (progress in the areas of quality, design, technology). Proper management of the products life cycle and reasonable innovation management are necessary tools for updating relevance of the products towards consumers.

Care for employees (employer attractiveness based on employee surveys). Presently, a lot of organizations have serious problems with finding and maintaining employees. The human factor is critical for business performance. To solve this problem, it is necessary to build a positive online image which represents the organization as a good employer.

Manage negative customer feedback (initiate a positive response as soon as possible and take care of the problem smoothly). This means creating a proactive policy towards the current reputation strategy setting caused by external factors. Assessment of possible risk is critical here. All actions must be conducted according to the assessment results.

Track current trends and adapt them. All businesses must track current trends and analyze them in order to find realistic scenarios of adaptation or utilization. From another point of view, if the business acts as a "trend setter", it is quite certain that, in the near future, it will be followed be competitors.

Have interest in the brand's customer satisfaction. The branding process is based on building and development of the brand's awareness between consumers. A significant criterium to achieve a necessary level of awareness is to understand to the customers' perspective. This understanding must be focused on knowledge about how customers perceive the brand and if the brand represents a certain value for them.

Effective use of available ICT. For a company's competitiveness, it is crucial to use recent ICT to analyze and manage its online reputation. Small companies can choose from free or more available, but less complex, solutions. Bigger or wealthier companies can choose from many robust and complex systems.

Focus on current development, mainly, a strong focus on actual trends in ICT and in the online environment. Additionally, focus on actual customers' behaviour and the current actions of competitors.

Author Contributions: All authors participated in the research and shared joint responsibility for this work.

Funding: This work was supported by the Slovak Research and Development Agency under the contract No. APVV-15-0511".

Acknowledgments: This paper was supported by the Slovak republic scientific grant "APVV-15-0511".

Conflicts of Interest: The authors declare no conflict of interest.

\section{References}

1. Alon, A.; Vidovic, M. Sustainability performance and assurance: Influence on reputation. Corp. Reput. Rev. 2015, 18, 337-352. [CrossRef]

2. Dorčák, P.; Markovič, P.; Pollák, F. Multifactor analysis of online reputation of selected car brands. Procedia Eng. 2017, 192, 719-724. [CrossRef]

3. Loureiro, S.; Sarmento, E.; Le Bellego, G. The effect of corporate brand reputation on brand attachment and brand loyalty: Automobile sector. Cogent Bus. Manag. 2017, 4. [CrossRef]

4. Sandu, M. Reputation—An Important Element for Automotive Industry Profit? Procedia Econ. Financ. 2015, 32, 1035-1041. [CrossRef] 
5. Prezentácie. Available online: http://people.tuke.sk/jan.paralic/prezentacie/MZ/MZ8.pdf (accessed on 2 June 2018).

6. Jones, B.; Temperley, J.; Lima, A. Corporate reputation in the era of Web 2.0: The case of Primark. J. Mark. Manag. 2009, 25, 927-939. [CrossRef]

7. Pang, B.; Lee, L. Opinion Mining and Sentiment Analysis. Found. Trends Inf. Retr. 2008, 2, 1-135. [CrossRef]

8. Hung, Y.; Huang, T.; Hsieh, J.; Tsuei, H.; Cheng, C.; Tzeng, G. Online reputation management for improving marketing by using a hybrid MCDM model. Knowl.-Based Syst. 2012, 35, 87-93. [CrossRef]

9. Liu, L.; Munro, M. Systematic analysis of centralized online reputation systems. Decis. Support Syst. 2012, 52, 438-449. [CrossRef]

10. Dorčák, P.; Markovič, P.; Pollák, F. Multifactor Analysis of Online Reputation as a Tool for Enhancing Competitiveness of Subjects from Automotive Industry. J. Econ. 2017, 2, 173-186.

11. Jung, J.C.; Park, S.B. Case study: Volkswagen's Diesel Emissions Scandal. Thunderbird Int. Bus. Rev. 2016, 59, 127-137. [CrossRef]

12. VW Zaplatí USA za Emisný Podvod 4,3 Miliardy Dolárov. Available online: https://spravy.pravda.sk/ ekonomika/clanok/416533-vw-zaplati-usa-za-emisny-podvod-4-3-miliardy/ (accessed on 5 May 2017).

13. Chen, Y.; Lai, S.; Wen, C. The influence of green innovation performance on the corporate advantage in taiwan. J. Bus. Ethics 2006, 67, 331-339. [CrossRef]

14. Lubin, D.A.; Esty, D.C. 'The sustainability imperative. Harv. Bus. Rev. 2010, 88, 42-50.

15. Gardberg, N.A.; Fombrun, C.J. Corporate citizenship: Creating intangible assets across institutional environments. Acad. Manag. Rev. 2006, 31, 329-346. [CrossRef]

16. Freedman, M.; Stagliano, A.J. Sustainability reputation and environmental performance or "the proof of the pudding is in the eating". Ethics Equity Regul. 2010, 15, 61-74. [CrossRef]

17. Little, P.L.; Little, B.L. Do Perceptions of Corporate Social Responsibility Contribute to Explaining Differences in Corporate Price-Earnings Ratios? A research note. Corp. Reput. Rev. 2000, 3, 137-142. [CrossRef]

18. Breton, P. Goodwill Rules: Managing Client Relationships: A Modus Operandi for Sales, Marketing $\mathcal{E}$ Advertising Managers; Lulu Press: Morrisville, NC, USA, 2013; ISBN 978-1-4357-1170-9.

19. Bakos, L.; Dumitraşcu, D.D. Holonic Crisis Handling Model for Corporate Sustainability. Sustainability 2017, 9, 2266. [CrossRef]

20. Bergman, M.M.; Bergman, Z.; Berger, L. An Empirical Exploration, Typology, and Definition of Corporate. Sustainability 2017, 9, 753. [CrossRef]

21. Michelon, G. Sustainability disclosure and reputation: A comparative study. Corp. Reput. Rev. 2011, 14, 79-96. [CrossRef]

22. Leaniz, P.M.G.; Bosque, I.R. Intellectual capital and relational capital: The role of sustainability in developing a corporate reputation. Intang. Cap. 2013, 9, 262-280. [CrossRef]

23. Lourenc. The Value Relevance of Reputation for Sustainability Leadership. J. Bus. Ethics 2014, 119, 17-28. [CrossRef]

24. Bebbington, J.; Larrinaga, C.; Moneva, J.M. Corporate social reporting and reputation risk management. Account. Audit. Account. J. 2008, 21, 337-361. [CrossRef]

25. Klein, J.; Dawar, N. Corporate social responsibility and consumers' attributions and brand evaluations in a product-harm crisis. Int. J. Res. Mark. 2004, 21, 203-217. [CrossRef]

26. Slováci a Česi Nad'alej Kral'ujú vo Výrobe áut na Obyvatel'a. Ako sa Bude Tento Stav Vyvíjat'? Available online: https: / finweb.hnonline.sk/ekonomika/937981-slovaci-a-cesi-nadalej-kraluju-vo-vyrobe-aut-naobyvatela-ako-sa-bude-tento-stav-vyvijat (accessed on 5 May 2017).

27. Toto sú Najpredávanejšie Autá a Značky na Slovensku za November: Kral'uje Mladoboleslavský Triumvirát. Available online: https:/ / www1.pluska.sk/Auto/Toto-su-najpredavanejsie-auta-a-znacky-na-Slovenskuza-november-Kraluje-mladoboleslavsky-triumvirat (accessed on 5 May 2017).

28. Sentiment Analysis and Opinion Mining. Available online: https://www.cs.uic.edu/ \{\}liub/FBS/ SentimentAnalysis-and-OpinionMining.pdf (accessed on 2 June 2018).

29. DanielSoper Free Sentiment Analyzer. Available online: https://www.danielsoper.com/sentimentanalysis/ default.aspx (accessed on 25 June 2017).

30. A Global Number of Volkswagen AG Employees from FY 2008 to FY 2017 (in 1000s)*. Available online: https: / / www.statista.com/statistics / 272052/worldwide-number-of-volkswagen-group-employees / (accessed on 5 June 2017). 
31. Brands \& Models. Available online: https://www.volkswagenag.com/en/brands-and-models.html (accessed on 5 June 2017).

32. VW Takes Global Sales Crown from Toyota Despite Diesel Crisis. Available online: https://www.bloomberg. com/news / articles / 2017-01-30/toyota-loses-sales-crown-to-vw-as-threat-of-trade-barriers-looms (accessed on 5 June 2017).

33. Production. Available online: http:/ / annualreport2016.volkswagenag.com/group-management-report/ sustainable-value-enhancement/production.html (accessed on 5 June 2017).

34. VW Profits Down 20\% after Diesel Emissions Scandal. Available online: https://www.theguardian.com/ business/2016/may/31/vw-volkswagen-profits-down-20-diesel-emissions-scandal (accessed on 5 June 2017).

35. What Is the Reputation Damage of VW's Emissions Admission? Available online: http:/ /www.alva-group. com/en/reputation-damage-vw-emissions-scandal/ (accessed on 5 June 2017).

36. Innovative Technology. Available online: http://webspecial.volkswagen.de/innovative-technologies/com/ en/mainpage.html (accessed on 5 June 2017).

37. WRC 2 Results. Available online: https://www.wrc.com/factbook/2016-2017/\#14 (accessed on 6 June 2017).

38. VW Končí s Vrcholovým Motoršportom! Opúšt’a WRC! Available online: https://www.topspeed.sk/ volkswagen-konci-s-vrcholovym-motorsportom-opusta-wrc/11367 (accessed on 6 June 2017).

39. Sorry, Volkswagen's Rescued 2017 Rally Car Won't Race This Year After All. Available online: https: / /jalopnik.com/sorry-volkswagens-rescued-2017-rally-car-wont-race-thi-1790695220 (accessed on 6 June 2017).

40. World Car Awards-2017 Voting Results. Available online: http://www.wcoty.com/web/2017_results.asp (accessed on 6 June 2017).

41. How Vw Lost the Public's Trust. Available online: https://www.reputationinstitute.com/volkswagen.aspx (accessed on 6 June 2017).

42. Volkswagen je Najväčšou Firmou Slovensko, Automotive Ťahá Ekonomiku. Available online: https: / / www.forbes.sk/volkswagen-najvacsou-firmou-slovenska-automotive-taha-ekonomiku/\# (accessed on 6 June 2017).

43. Bratislavský Volkswagen Očaril Európu. Získal Prestížne Ocenenie. Available online: https://finweb. hnonline.sk/ekonomika/573131-bratislavsky-volkswagen-ocaril-europu-ziskal-prestizne-ocenenie (accessed on 6 June 2017).

44. Investor Roka 2016 je Volkswagen Slovakia. Available online: https:/ / www.etrend.sk/trend-archiv / rok2016/ cislo-45/volkswagen-investuje-vela-a-rozumne.html (accessed on 7 June 2017).

45. Naj Zamestnávatel'. Available online: http://www.najzamestnavatel.sk/rebricek-2016/ (accessed on 7 June 2017).

46. Duálna Akadémia Ponúka Krátkodobé Kurzy! Available online: http://dualnaakademia.sk/ponukakratkodobych-kurzov / (accessed on 7 June 2017).

47. Volkswagen Is Now the Biggest Car Manufacturer in the World. Available online: http:/ /www.autoexpress. co.uk/volkswagen/98474/volkswagen-is-now-the-biggest-car-manufacturer-in-the-world (accessed on 12 June 2017).

48. Most and Least Expensive Cars to Maintain. Available online: https://www.yourmechanic.com/article/themost-and-least-expensive-cars-to-maintain-by-maddy-martin (accessed on 12 June 2017).

49. Employees. Available online: http://www.toyota-global.com/sustainability/society/employees/sdb16_ so06_en.pdf (accessed on 12 June 2017).

50. Toyota Employee Reviews. Available online: https://www.indeed.com/cmp/Toyota/reviews?fcountry= ALL (accessed on 12 June 2017).

51. Toyota Awards \& Ratings. Available online: https:/ / www.toyota.com/awards/ (accessed on 12 June 2017).

52. Toto Sú Najpredávanejšie Autá na Slovensku za Jún a Prvý Polrok Tohto Roku! Available online: https:// www1.pluska.sk/Auto/Toto-su-najpredavanejsie-auta-na-Slovensku-za-jun-a-prvy-polrok-tohto-roku (accessed on 13 June 2017).

53. Návštenost'. Available online: https://medialne.etrend.sk/internet-grafy-a-tabulky.html (accessed on 13 June 2017). 
54. SME. Available online: https://www.sme.sk/search?q=toyota\&order=relevance\&period=90 (accessed on 13 June 2017).

55. Aktuality. Available online: https://www.aktuality.sk/vyhladavanie/?q=toyota (accessed on 13 June 2017).

56. Topky. Available online: https://www.topky.sk/search/toyota/ (accessed on 13 June 2017).

57. Pravda. Available online: https://www.pravda.sk/vyhladavanie/?q=toyota\&cx=CSE_CX\&cof=CSE_ FORID\&ie=utf-8\&as_sitesearch= (accessed on 13 June 2017).

58. ToyotaTeam Slovakia. Available online: http://www.toyotateam.sk/forum/ (accessed on 13 June 2017).

59. TEST: Toyota Corolla 1,6 Valvematic-Spol'ahlivost's Komfortom. Available online: https:/ / podkapotou. zoznam.sk/cl/1000614/1535301/TEST--Toyota-Corolla-1-6-Valvematic---spolahlivost-s-komfortom (accessed on 13 June 2017).

60. Tokyo Motor Show Sets 2017 Dates, Vows Boost in Attendance. Available online: http: / / www.autonews.com/article/20160915/RETAIL03/160919903/tokyo-motor-show-sets-2017-datesvows-boost-in-attendance (accessed on 13 June 2017).

61. Toyota Gazoo Rating. Available online: http://www.toyota-global.com/events/motor_sports/ (accessed on 13 June 2017).

62. Toyota Dream Car Art Contest. Available online: http://www.toyota-global.com/events/dream_car_art_ contest/ (accessed on 13 June 2017).

63. Toyota Social Media. Available online: http://www.toyota-global.com/company/social/ (accessed on 13 June 2017).

64. Zverejnili Rebríček 25 Najspol'ahlivejších Značiek Áut na Svete. Available online: https: / www.aktuality.sk / clanok/513689/zverejnili-rebricek-25-najspolahlivejsich-znaciek-aut-na-svete/ (accessed on 14 June 2017).

65. Top Gear's Guide to: Kia. Available online: https://www.topgear.com/car-reviews/find/make/kia (accessed on 14 June 2017).

66. Future Brand Vision. Available online: http://pr.kia.com/en/main.do (accessed on 14 June 2017).

67. Sponzorstvá. Available online: https://www.kia.com/sk/o-nas/kia-zazitok/znacka/sponzorstva/ (accessed on 14 June 2017).

68. Kia: America's Most Reliable Car Brand, Study Shows. Available online: https://www.thestreet.com/story/ 13616784/1/kia-america-s-most-reliable-car-brand-study-shows.html (accessed on 14 June 2017).

69. Slávnostné Otvorenie Závodu Kia Motors Slovakia. Available online: http://www.kia.sk/sk/clanok/ slavnostne-otvorenie-zavodu-kia-motors-slovakia (accessed on 19 June 2017).

70. Kia Motors Slovakia Plánuje Zvýšit' Mzdy o Sto Eur. Available online: https://spravy. pravda.sk/ekonomika/clanok/424059-kia-motors-slovakia-planuje-zvysit-mzdy-o-sto-eur/ (accessed on 19 June 2017).

71. Vít'azom Národnej Ceny Za Kvalitu Je Spoločnost’ Kia Motors Slovakia. Available online: http:// www.kia.sk/sk/clanok/vitazom-narodnej-ceny-za-kvalitu-je-spolocnost-kia-motors-slovakia (accessed on 19 June 2017).

72. Kia Motors Slovakia Medzi Najväčšími Firmami Slovenska. Available online: http://www.kia.sk/sk/ clanok/kia-motors-slovakia-medzi-najvacsimi-firmami-slovenska (accessed on 19 June 2017).

73. Mesto Ocenilo Pomoc Spoločnosti Kia Motors Slovakia. Available online: http://www.kia.sk/sk/clanok/ mesto-ocenilo-pomoc-spolocnosti-kia-motors-slovakia (accessed on 19 June 2017).

74. Kia Sportage zo Slovenska Dosahuje v Európe Rekordné Predaje. Available online: http://www.kia.sk/sk/ clanok/kia-sportage-zo-slovenska-dosahuje-v-europe-rekordne-predaje (accessed on 20 June 2017).

75. Kia Sportage je Najkvalitnejšia. Available online: http://www.kia.sk/sk/clanok/kia-sportage-jenajkvalitnejsia (accessed on 20 June 2017).

76. Kia Sportage Stanovila Nový Rekord v Dvojročnom Teste Spol'ahlivosti. Available online: http:// www.kia.sk/sk/clanok/kia-sportage-stanovila-novy-rekord-v-dvojrocnom-teste-spolahlivosti (accessed on 20 June 2017).

77. Anketa: Aké Výhody Poskytujete Zamestnancom? Available online: https://finweb.hnonline.sk/ ekonomika/527376-anketa-ake-vyhody-poskytujete-zamestnancom (accessed on 20 June 2017).

78. Nadačný Fond Kia Motors Slovakia v Nadácii Pontis. Available online: https://www.nadaciapontis.sk/ nadacny-fond-kia-motors-slovakia (accessed on 20 June 2017).

79. Nadácia. Available online: http:/ / www.nadaciakia.sk (accessed on 20 June 2017). 
80. Agentúra Moody's Zlepšila Rating Koncernu PSA. Available online: https:/ / finweb.hnonline.sk/ financie-aburzy/520132-agentura-moody-s-zlepsila-rating-koncernu-psa (accessed on 21 June 2017).

81. Peugeot Dakar 2018. Available online: https://www.peugeot.sk/znacka-a-technologia/sport/dakar.html (accessed on 21 June 2017).

82. Engine. Available online: https://www.ukimediaevents.com/engineoftheyear/index.php (accessed on 21 June 2017).

83. Mid-size SUV of the Year 2017: Peugeot 3008. Available online: http:/ / www.autoexpress.co.uk/peugeot/ 3008/99855/mid-size-suv-of-the-year-2017-peugeot-3008 (accessed on 21 June 2017).

84. Peugeot 3008 Announced Car of the Year 2017. Available online: http://www.caroftheyear.org/noticias/05. php (accessed on 21 June 2017).

85. Peugeot 3008: Prerod na SUV sa Podaril. Available online: https://autobild.cas.sk/clanok/212186/peugeot3008-prerod-na-suv-sa-podaril/ (accessed on 21 June 2017).

86. Historique Dakar. Available online: https://web.archive.org/web/20130614234211/http:/www.dakar.com/ 2011/DAK/presentation/docs/historique-dakar-1979-2009_us.pdf (accessed on 21 June 2017).

87. Final CD. Available online: https://www.finalcd.sk/news/177-akcia_tvrdak_2017/ (accessed on 21 June 2017).

88. Peugeot či Kofola, Slovenské Predsedníctvo Má 13 Sponzorov. Available online: https: / / ekonomika.sme.sk/ c/20205336/ peugeot-ci-kofola-slovenske-predsednictvo-ma-13-sponzorov.html (accessed on 21 June 2017).

89. Fertik, M.; Thomson, D. Wild West 2.0: How to Protect and Restore Your Reputation on the Untamed Social Frontier; Amacom: New York, NY, USA, 2010; ISBN 978-0-8144-1509-2.

90. Keller, K.L. Strategic Brand Management: Building, Measuring, and Managing Brand Equity; Pearson: London, UK, 2015; ISBN 978-0132664257.

91. Firmy Odmietajú Zákazky pre Nedostatok Pracovnej Sily. Available online: https://profesia.pravda. sk/ludske-zdroje/clanok/473179-firmy-odmietaju-zakazky-pre-nedostatok-pracovnej-sily/ (accessed on 19 June 2017).

92. Keller, K.L. The Brand Report Card. Harvard Business Review, January-February 2000.

93. Delai, I.; Takahashi, S. Sustainability measurement system: A reference model proposal. Soc. Responsib. J. 2011, 7, 438-471. [CrossRef]

94. Dyllick, T.; Hockerts, K. Beyond the Business Case for Corporate Sustainability. Bus. Strategy Environ. 2002, 11, 130-141. [CrossRef]

95. Mikalef, P.; Pateli, A. Information technology-enabled dynamic capabilities and their indirect effect on competitive performance: Findings from PLS-SEM and fsQCA. J. Bus. Res. 2017, 70, 1-16. [CrossRef] 